\title{
PRE-ALPINE MIGMATITIC ROCKS AND ACID TO INTERMEDIATE ORTHOGNEISSES IN PENTELIKON MOUNTAIN (NE ATTICA, GREECE)
}

\author{
Baziotis I. ${ }^{1}$, Mposkos E. ${ }^{1}$, and Perdikatsis V. ${ }^{2}$ \\ ${ }^{1}$ Department of Geological Sciences, School of Mining and Metallurgical Engineering, National \\ Technical University of Athens, 9 Heroon Polytechniou Str., 157 80, Zografou (Athens), Greece, \\ baziotis@metal.ntua.gr, mposkos@metal.ntua.gr \\ ${ }^{2}$ Department of Mineral Resources Engineering, Technical University of Crete, 73 100, Chania, \\ Greece,Vperdik@mred.tuc.gr
}

\begin{abstract}
In the broad area of Pentelikon Mountain, which is part of the Attic-Cycladic crystalline belt, metamigmatites and orthogneisses occur as tectonic slices within the calc-schists or between calcschists and marbles. In the metamigmatites relic of migmatitic fabrics, comprising leucosomes and melanosomes, and crosi-cutting aplitic and pegmatitic dykes are still preserved. The orthogneisses have dioritic to granitic composition. They are interpreted to be probably formed in a magmatic arc setting. Granitic orthogneisses show high-K contents and are enriched in LILEs and depleted in HFSEs. They also exhibit fractionated REE patterns with slight to strong negative Eu anomaly. The exceptionally high $\mathrm{K}_{2} \mathrm{O}$ contents $(>7 \%)$ and the very low $\mathrm{Na}_{2} \mathrm{O}$ contents $(0.4-0.98$ wt\%) of certain phengite-orthogneisses with ultramylonitic textures are attributed to metasomatic processes that occurred during ultramylonitization.
\end{abstract}

\section{INTRODUCTION}

The broad area of Pentelikon Mountain is part of the Attic-Cycladic crystalline complex. This complex underwent HP/LT metamorphism of blueschist to eclogite facies conditions during the Eocene (ca. 50-40 Ma), and a Barrovian-type overprint of greenschist to amphibolite facies conditions during Oligocene/Miocene (ca. 25-20 Ma) (i.e. Wijbrans et al., 1990 and references therein). A PreAlpine basement comprising metamigmatites, pelitic gneisses, amphibolites and orthogneisses crop out in several Cycladic islands i.e. Naxos, Paros, los and Sikinos (i.e. Andriessen et al. 1987, Engel \& Reischmann 2001)

In the area of Pente'ikon Mountain a variety of gneissic rocks occur, tectonically intercalated in the calc-schists or between calc-schists and marbles. The most predominant types of these gneisses are leucocratic phengite-orthogneisses, darker amphibole-epidote-albite-orthogneisses and metamigmatites.

Katsikatsos (1977), Kessel (1990) and Lozios (1993), studied in detail the lithostratigraphy and tectonics of the broad area of Pentelikon Mountain. They suggest an Alpine age for the protoliths of all metamorphic rocks, including the orthogneisses and metamigmaties based on their lithostratigraphic criteria and rare but still preserved fossils in the marbles. In the lithostratigraphic succession given by Katsikatsos the gneisses overlie the Triassic Pentelikon marbles, whereas in that given by Lozios the gn: sisses underlie the Pentelikon marbles. According to the Katsikatsos and Lozios, Pre-Alpine lithologies, like those of the metamigmatites are not comprised in the metamorphic rocks of the Pentelikon Mountain.

In this work we present field observations, petrography, mineral chemistry and geochemistry for the metamigmatites and the orthogneisses of the Pentelikon Mountain and we discuss their significance to the geotectonic evolution of the area. 


\section{GEOLOGICAL BACKGROUND}

The area of Pentelikon Mountain is built up of metamorphic rocks. Based on the geological map of Lozios (1993) (Fig. 1) the Pentelikon Mountain consists of a volcanosedimentary series at the base comprising pelitic schists, calc-schists with marble intercalations and quartz-feldspathic rocks (including the metamigmatites and orthogneisses of the present work). A thick carbonate series of Triassic to Cretaceous age follows and Eocene flysch is at the top. Lenses of mafic and ultramafic rocks are also present within the calc-schists and marbles.

Continuous penetrative deformational events occurred during the various stages of tectonometamorphic evolution of the Pentelikon complex. The overall structure is characterized by folding, transpositions and large-scale imbrications, resulting to the disturbance of the original lithostratigraphic succession and to the repetition of lithologies.

Relics of glaucophar.e and pumpellyite preserved as inclusions in clinozoisite, albite and garnet of the calc-schists and metabasites, and high-Si phengites within the orthogneisses and metamigmatites, indicate that the Pentelikon Mountain underwent HP/LT metamorphism. Geothermobarometric calculations based on analyzed mineral compositions constrain the P-T conditions at $\sim 13 \mathrm{Kbar}$ and $350-400^{\circ} \mathrm{C}$ (Baziotis et al. 2004). During exhumation a greenschist facies metamorphism overprinted the blueschists facies event, as indicated by the neoformation of albite porphyroblasts at the expense of glaucophane and paragonite (?), the replacement of garnet by chlorite and the formation of actinolitic hornblende in the calc-schists and metabasites.

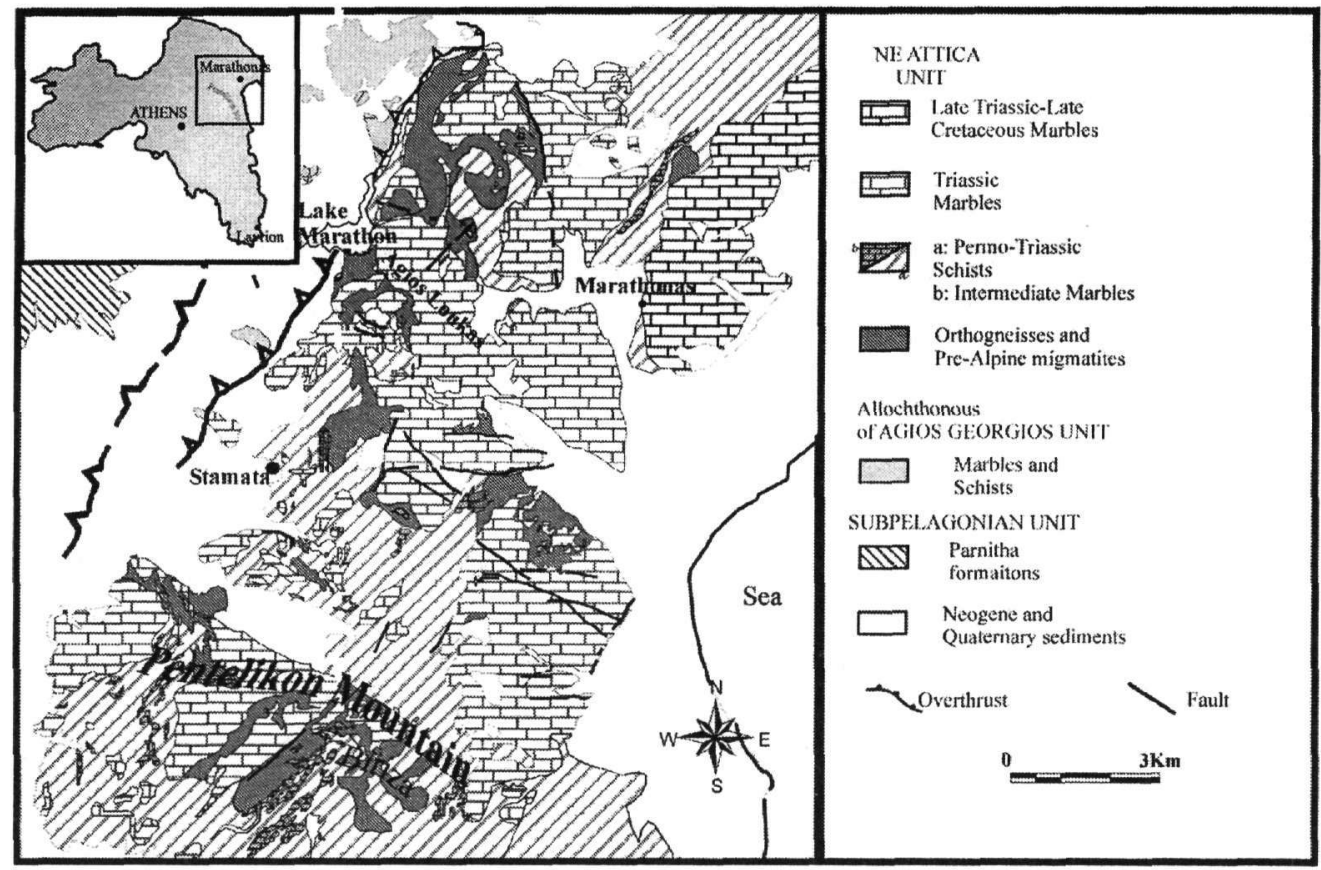

Figure 1. Simplified geological map of NE Attica, showing the extent of metamigmatites and orthogneisses in the broad area of Pentelikon Mountain (after Lozios 1993)

\section{FIELD RELATIONS AND PETROGRAPHY OF METAMIGMATITES AND ORTHOGNEISSES}

\subsection{Metamigmatites}

Metamigmatites and orthogneisses occur as tectonic slices and lenses ranging from hundred meters to more than one kilometer long, intercalated within calc-schists or between calc-schists and marbles. Metamigmatites preserve relics of their migmatitic fabric, indicated by alternating leuco- 
cratic and melanocratic layers (the former represent anatectic leucosomes) or by centimeter to decimetre long lensoidal melanocratic parts. In some places the melanocratic layers are several meters long and up to 60 centimeter thick, indicating a high degree of partial melting in the migmatite. Deformed aplitic and pegmatitic dykes are subparallel or cross-cut the main foliation of the host migmatitic gneisses. In certain cases the pegmatitic dykes are isoclinally folded or boudinaged forming isolated lenses. The most typical metamigmatite bodies are located on the forest road to Biriza $38^{\circ} 03^{\prime} 96^{\prime \prime} \mathrm{N} 23^{\circ} 54^{\prime} 64^{\prime \prime} \mathrm{E}$ and NW of Agios Nikolaos $38^{\circ} 03^{\prime} 77^{\prime \prime} \mathrm{N} 23^{\circ} 55^{\prime} 10^{\prime \prime} \mathrm{E}$. Figures 2 and 3 show metamigmatites from an outcrop on the forest road to Biriza. Figure 2 shows well preserved alternating melanocratic and leucocratic layers, corresponding to previous leucosomes and melanosomes. The leucocratic layers consist of microcline-albite-quartz-phengite and the melanocratic ones of biotite-phengite-quartz-microcline-albite. Biotite and phengite are predominant phase, while albite and microcline present in minor amounts. In figure 4 a pegmatitic dyke crosscuts the foliation of the metamigmatitic gneiss. The dyke is deformed and shows the same foliation as that of the gneiss, indicating that the intrusion of the dyke in the metamigmatite predates deformation.

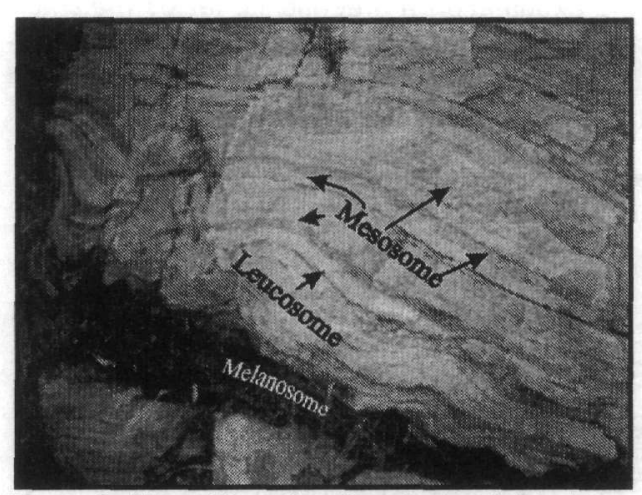

Figure 2. Migmatite with alternations of thin leucocratic and melanocratic layers. A thick biotite-rich restite layer is visible at the bottom. (On road to Biriza area)

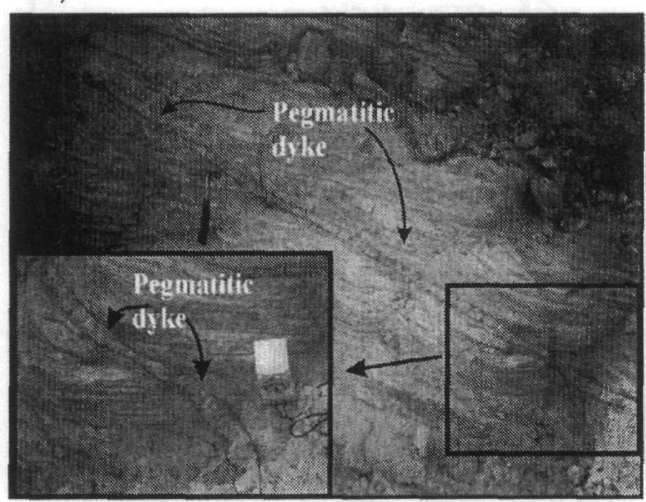

Figure 4. Syndeformational pegmatitic dyke cross-cut the foliation of the migmatite

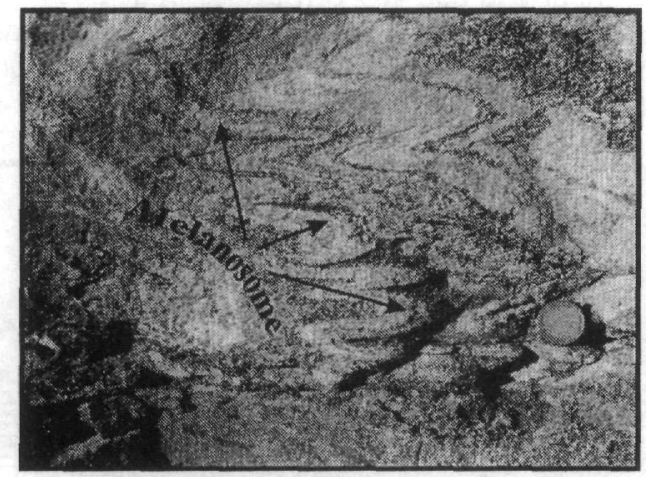

Figure 3. Migmatite characterized by folded leucocratic and melanocratic layers. (On forest-road to Biriza area)

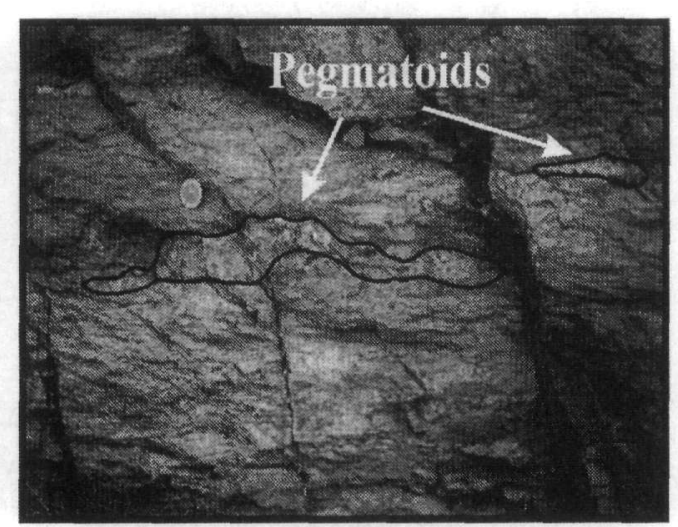

Figure 5. Deformed pegmatoid lenses in migmatite (I0cality NW of Agios Nikolaos). 


\subsection{Orthogneisses}

The orthogneisses are represented by light coloured phengite-gneisses and dark coloured amphibole-epidote-albite gneisses. Penetrative deformation led to mylonite and ultramylonite formation (Figs. 6 and 7). The phengite-gneisses occur commonly as augen-gneisses with the mineral assemblage microcline-quartz-phengite \pm albite \pm biotite. Zircon, apatite and opaques are present as accessory minerals.

Microcline occurs as coarse-grained porphyroclasts, commonly with Karlsbad twinning (Fig. 6). Inclusions of magmatic plagioclase showing corroded edges are also present. Microcline has a characteristic clouded appearance in the inner part and an outer water clear zone (Fig. 6). The clouded part is possibly attributed to incipient alteration of cryptoperthitic exsolutions and the outer water clear outer zone to microcline overgrowth during mylonitization process. Microcline is the predominant mineral in a fine-grained matrix (Fig. 7). It possibly formed by dynamic recrystallization under high differential stresses. In these domains quartz grains are completely recrystallized with the development of flattened quartz ribbons. These high strain domains represent ultramylonite layers (Fig. 7) surrounding microlithons of quartz and microcline that preserve older textures.

Quartz is medium-grained and shows commonly undulatory extinction. It occurs in ribbons elongated parallel to the foliation or as strain-free grains showing triple junctions unequal to $120^{\circ}$ formed by dynamic recrystallization. In certain domains quartz is formed by static recrystallization, as shows by strain-free grains with triple junctions equal to $120^{\circ}$.

Albite occurs as anhedral grains in the matrix. It is also preserved as subhedral inclusions in the clouded inner part of the microcline porphyroclasts, and is interpreted to be of magmatic origin.

Phengite occurs as fine-grained flakes enclosed in microcline, or as medium-grained clasts with characteristic mica fish shape (Fig. 7), showing stair-stepping trails and in certain cases as isolated grains. Phengite also occurs as resorbed flakes parallel or oblique to the foliation. Phengite is rich in iron, and shows zoning with a pale green rim and a colourless core. Biotite, when present, is intergrown with muscovite parallel to the schistosity. It is often replaced by chlorite.

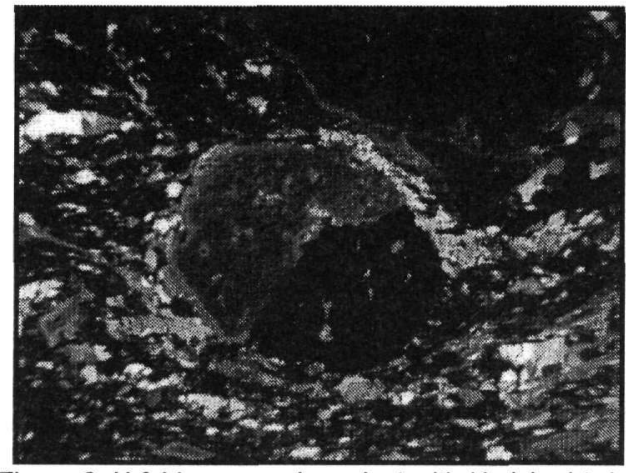

Figure 6. K-feldspar porphyroclast with Karlsbad twinning. It shows a clouded inner part and a water clear outer zone. Micas forms anastomosing structure that surround the K-feldspar porphyroclast.

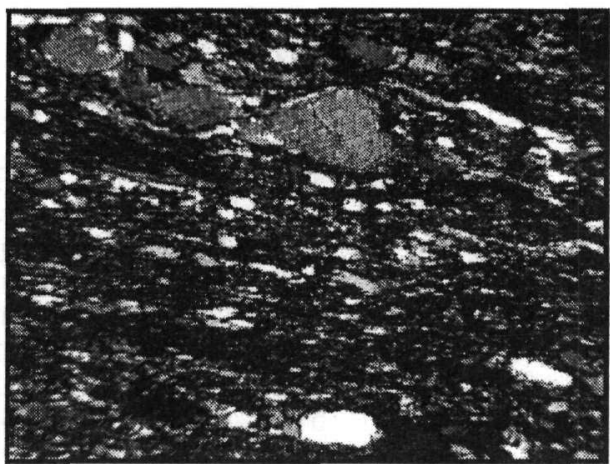

Figure 7. Ultramylonitic texture with flattened quartz ribbons in a fine-grained matrix rich in K-feldspar. At the upper part occur resorbed phengites clasts with mica-fish shape.

In ultramylonite domains the fine-grained K-feldspar dominates (Fig. 7). Phengite is present as relics with corroded edges (Fig. 7) while albite is almost absent. This is interpreted to be due to a metasomatic process involving $\mathrm{K}$-feldspathization of albite and phengite with influx of K-bearing fluids and removal of $\mathrm{Na}$, leading to the increase of $\mathrm{K}_{2} \mathrm{O}$ and decrease of $\mathrm{Na}_{2} \mathrm{O}$ content in the rock (see below geochemistry).

The amphibole-epidote-albite-orthogneisses have the mineral assemblage albite-green amphibole-epidote/clinozoisite-quartz-biotite-phengite-chlorite \pm calcite.

Albite occurs as medium to coarse-grained porphyroblasts containing inclusions of phengite, epidote and green amphibole. Epidote is present as coarse-grained crystals or medium-grained aggregates. Biotite, phengite and chlorite flakes are oriented parallel to the foliation of the rock. In 
most cases biotites anastomose albite porphyroblasts and/or produce characteristic C'-type shear band cleavages. Green amphibole forms prismatic crystals oriented parallel to the foliation. It also forms, together with biotite, anastomosing structures around albite. Fine prismatic amphiboles are commonly present as or ented inclusions in albite porphyroblasts.

\section{MINERAL CHEMISTRY}

Representative compositions of phengite and biotite from two samples of orthogneisses (performed by electron microprobe) are given in table 1. The Si values of phengite range from 6.9-7.26 atoms per formula unit (a.p.f.u.). Higher Si values are observed in phengites from sample PE4, that contains biotite as additional phase. There is also a slight tendency for the $\mathrm{Mg} /(\mathrm{Mg}+\mathrm{Fe})$ to increase with increasing Si. Phengite showing such Si-values are common from high-pressure terranes, and are in accordance with he blueschists facies metamorphism of the Pentelikon metamorphic complex (Kessel 1990, Baziotis et al. 2004). The amounts of $\mathrm{Mg}+\mathrm{Fe}^{+2}$ tot in phengite exceeds Si- 6 by 0.003 to 0.568 a.p.f.u. This indicates that appreciable amounts of the iron is in trivalent state substituting for $\mathrm{Al}^{\mathrm{VI}}$. Phengite shows compositional zoning with increasing $\mathrm{Fe}$ and decreasing $\mathrm{Al}$ from the core to the rim ( $\mathrm{Tab} .1$ ) indicating increasing substitution of $\mathrm{Fe}^{+3}$ for $\mathrm{Al}$ toward the rim. Biotite has $\mathrm{Mg} /(\mathrm{Mg}+\mathrm{Fe})$ ratio ranging from 0.46 to 0.50 . The $\mathrm{Al}^{\mathrm{IV}}$ and $\mathrm{Ti}$ values range from 2.04 to 2.06 and from 0.32 to 0.36 a.p.f.u respectively. The An-content in albite ranges from $0-2 \%$.

Table 1: Representative compositions of phengite and biotite from two samples of phengite-orthogneisses.

\begin{tabular}{|c|c|c|c|c|c|c|c|c|c|}
\hline Sample & $\begin{array}{l}\text { 97P9 } \\
\text { Phg }^{\prime}\end{array}$ & $\begin{array}{l}97 \overline{P g} \\
\mathrm{Phg}^{\mathrm{c}}\end{array}$ & $\mathrm{Phg}^{\mathrm{R}}$ & $\mathrm{Phg}^{\mathrm{R}}$ & $\begin{array}{l}\text { PE4 } \\
\text { Phg }^{c}\end{array}$ & $\mathrm{Phg}^{\mathrm{R}}$ & $\begin{array}{l}\mathrm{PE} 4 \\
\mathrm{Bt}^{1}\end{array}$ & $\mathrm{Bt}^{2}$ & $\mathrm{Bt}^{3}$ \\
\hline $\mathrm{SiO}_{2}$ & 49.75 & 52.00 & 51.03 & 50.89 & 52.56 & 52.48 & 39.34 & 39.66 & 39.12 \\
\hline $\mathrm{TiO}_{2}$ & 0.83 & 0.24 & 0.24 & 0.92 & 1.04 & 0.98 & 2.86 & 3.15 & 3.05 \\
\hline $\mathrm{Al}_{2} \mathrm{O}_{3}$ & 28.62 & 24.80 & 23.5 & 22.53 & 22.98 & 20.57 & 16.66 & 16.91 & 15.65 \\
\hline $\mathrm{FeO}_{\mathrm{T}}$ & 2.46 & 4.68 & 8.60 & 5.42 & 3.78 & 6.10 & 16.86 & 15.27 & 17.09 \\
\hline MgO & 2.31 & 2.51 & 2.66 & 3.01 & 2.44 & 2.88 & 8.05 & 8.61 & 8.78 \\
\hline $\mathrm{CaO}$ & 0.10 & 0.00 & 0.00 & 0.00 & 0.00 & 0.00 & 0.7 & 0.52 & 0.11 \\
\hline $\mathrm{Na}_{2} \mathrm{O}$ & 0.09 & 0.00 & 0.00 & 0.20 & 0.29 & 0.12 & 0.61 & 0.63 & 0.46 \\
\hline $\mathrm{K}_{2} \mathrm{O}$ & 11.50 & 13.70 & 9.97 & 11.01 & 11.20 & 10.37 & 8.93 & 8.86 & 9.55 \\
\hline Total & 95.66 & 94.93 & 96.00 & 93.98 & 94.29 & 93.50 & 94 & 93.6 & 94 \\
\hline \multicolumn{10}{|c|}{ Cations based on 22 oxygen atoms } \\
\hline Si & 6.659 & 7.032 & 6.952 & 7.031 & 7.159 & 7.249 & 5.946 & 5.961 & 5.955 \\
\hline $\mathrm{Al}^{\mathrm{IV}}$ & 1.341 & 0.968 & 1.048 & 0.969 & 0.841 & 0.751 & 2.056 & 2.039 & 2.045 \\
\hline$A l^{1 / 2}$ & 3.173 & 2.985 & 2.726 & 2.700 & 2.847 & 2.597 & 0.914 & 0.957 & 0.763 \\
\hline Ti & 0.084 & 0.024 & 0.025 & 0.096 & 0.107 & 0.102 & 0.325 & 0.356 & 0.349 \\
\hline $\mathrm{Fe}^{+2}$ & 0.275 & 0.529 & 0.980 & 0.626 & 0.430 & 0.705 & 2.13 & 1.919 & 2.175 \\
\hline Mg & 0.461 & 0.506 & 0.540 & 0.620 & 0.495 & 0.593 & 1.814 & 1.929 & 1.993 \\
\hline $\mathrm{Ca}$ & 0.014 & 0.000 & 0.000 & 0.000 & 0.000 & 0.000 & 0.113 & 0.083 & 0.018 \\
\hline $\mathrm{Na}$ & 0.023 & 0000 & 0.000 & 0.054 & 0.077 & 0.032 & 0.178 & 0.182 & 0.135 \\
\hline K & 1.963 & 1.846 & 1.733 & 1.940 & 1.946 & 1.827 & 1.722 & 1.699 & 1.853 \\
\hline Total & 13.994 & 13.890 & 14.003 & 14.036 & 13.902 & 13.856 & 15.197 & 15.126 & 15.286 \\
\hline$X_{\mathrm{Mg}}$ & 0.63 & 0.49 & 0.35 & 0.50 & 0.53 & 0.46 & 0.46 & 0.50 & 0.48 \\
\hline
\end{tabular}

Total iron is determined as $\mathrm{FeO}$, i: inclusion in microcline

\section{GEOCHEMISTRY}

Chemical analyses of nine metamigmatites, nine phengite-orthogneisses and nine amphiboleepidote-albite-orthognei:ses were performed for major and trace elements. The REE were analysed for four samples of the amphibole-epidote-albite-orthogneisses and one sample from the phengite-orthogneisses. Major elements were determined by inductively coupled plasma emission spectromentry (ICP-ES) after $\mathrm{LiBO}_{2}$ fusion nitric digestion. The trace and rare earth elements (REE) of selected samples were determined by inductively coupled plasma mass spectromentry (ICP-MS) after $\mathrm{LiBO}_{2}$ fusion nitric digestion. All the analyses were carried out at Acme Analytical laboratories in Canada. Representative analyses are given in table 2. 
Table 2: Chemical compositions of representative samples for major (wt.\%), trace (ppm) and rare earth elements (REE) of leucosomes (Leu), melanosomes (Mel), phengite-orthogneisses (P.O.) and amphibole-epidotealbite-orthogneisses (A.O.) from Pentelikon Mountain. (ASI): Aluminium saturation index -: not determined

\begin{tabular}{|c|c|c|c|c|c|c|c|c|c|c|}
\hline Sample & $\begin{array}{l}3 \\
\text { Leu }\end{array}$ & $\begin{array}{l}46 \\
\mathrm{Mel}\end{array}$ & $\begin{array}{l}13 \\
\text { P.O. }\end{array}$ & $\begin{array}{l}18 \\
\text { P.O. }\end{array}$ & $\begin{array}{l}55 \\
\text { P.O. }\end{array}$ & $\begin{array}{l}53 \\
\text { A.O }\end{array}$ & $\begin{array}{l}38 \\
\text { A.O. }\end{array}$ & $\begin{array}{l}49 \\
\text { A.O. }\end{array}$ & $\begin{array}{l}50 \\
\text { A.O. }\end{array}$ & $\begin{array}{l}51 \\
\text { A.O. }\end{array}$ \\
\hline $\mathrm{SiO} 2$ & 71.92 & 46.53 & 72.15 & 71.35 & 74.21 & 49.34 & 66.22 & 60.69 & 58.90 & 57.96 \\
\hline TiO2 & 0.33 & 2.87 & 0.36 & 0.26 & 0.31 & 0.70 & 0.55 & 0.48 & 0.43 & 0.41 \\
\hline $\mathrm{Al} 2 \mathrm{O} 3$ & 13.87 & 25.00 & 13.77 & 13.80 & 11.88 & 20.47 & 12.42 & 15.29 & 16.82 & 14.42 \\
\hline $\mathrm{Fe} 2 \mathrm{O} 3$ & 2.30 & 8.19 & 2.50 & 2.62 & 1.73 & 9.32 & 7.24 & 6.30 & 6.05 & 6.26 \\
\hline $\mathrm{MnO}$ & 0.01 & 0.00 & 0.02 & 0.01 & 0.01 & 0.13 & 0.09 & 0.10 & 0.10 & 0.11 \\
\hline $\mathrm{MgO}$ & 0.55 & 4.81 & 0.74 & 0.31 & 0.52 & 3.72 & 2.88 & 1.90 & 2.55 & 3.74 \\
\hline $\mathrm{CaO}$ & 0.18 & 0.03 & 0.35 & 0.13 & 0.12 & 10.92 & 4.63 & 6.04 & 7.31 & 8.68 \\
\hline $\mathrm{Na} 2 \mathrm{O}$ & 2.30 & 0.09 & 2.42 & 0.42 & 0.98 & 2.89 & 2.15 & 2.25 & 4.00 & 2.04 \\
\hline $\mathrm{K} 2 \mathrm{O}$ & 7.51 & 7.63 & 6.46 & 9.50 & 7.40 & 0.46 & 2.04 & 1.49 & 0.30 & 1.81 \\
\hline $\mathrm{P} 2 \mathrm{O} 5$ & 0.14 & 0.07 & 0.05 & 0.59 & 0.01 & 0.07 & 0.13 & 0.07 & 0.05 & 0.06 \\
\hline LOI & 0.79 & 5.00 & 1.12 & 1.00 & 2.00 & 2.10 & 1.50 & 3.60 & 3.40 & 5.00 \\
\hline Sum & 99.91 & 100.21 & 99.94 & 99.99 & 99.17 & 100.12 & 99.84 & 98.21 & 99.91 & 100.52 \\
\hline $\mathrm{Mg \#}$ & 33 & 53 & 37 & 19 & 37 & 45 & 44 & 37 & 45 & 54 \\
\hline ASI & 1.38 & 3.22 & 1.49 & 1.37 & 1.4 & 1.44 & 1.41 & 1.56 & 1.45 & 1.15 \\
\hline $\mathrm{Zr}$ & 149 & 297 & 185 & 180 & 207 & 36.9 & 134 & 77.8 & 80.5 & 64.9 \\
\hline $\mathrm{Nb}$ & 6 & 14 & 11 & 14 & 10.1 & 1.2 & 11 & 4 & 4.6 & 3.6 \\
\hline$Y$ & 26 & 99 & 35 & 38 & 33.3 & 17.1 & 26 & 18 & 17.5 & 13.6 \\
\hline $\mathrm{Sr}$ & 56 & 6 & 36 & 24 & 48.3 & 225 & 136 & 188 & 174 & 339 \\
\hline $\mathrm{Rb}$ & 114 & 527 & 204 & 298 & 236 & 14.8 & 36 & 45.6 & 7.6 & 57.3 \\
\hline U & 6 & 11 & 2 & 4 & 4 & 0.4 & 2 & 1.7 & 1.6 & 5 \\
\hline Th & 6 & 6 & 8 & 7 & 27.4 & 1.2 & 4 & 4.7 & 5.9 & 4.1 \\
\hline $\mathrm{Pb}$ & 15 & 47 & 174 & 20 & 7,6 & 0.6 & 19 & 1.7 & 1.8 & 3.4 \\
\hline $\mathrm{Ni}$ & 4 & 102 & 6 & 4 & 0.5 & 17.4 & 9 & 7 & 3.7 & 41.2 \\
\hline $\mathrm{Cr}$ & 17 & 122 & 18 & 16 & $<1$ & $<8$ & 18 & $<3$ & $<1$ & 28 \\
\hline V & 16 & 280 & 25 & 21 & 33 & 339 & 114 & 203 & 183 & 181 \\
\hline $\mathrm{Ba}$ & 868 & 402 & 455 & 621 & 771 & 53 & 401 & 377 & 53 & 366 \\
\hline Ta & - & - & - & & 0,8 & $<0.1$ & - & 0.3 & 0.4 & 0.3 \\
\hline Cs & - & - & - & & 1.2 & 0.2 & - & 3.1 & 0.3 & 1.6 \\
\hline Sample & $\mathrm{La}$ & $\mathrm{Ce}$ & $\mathrm{Pr}$ & $\mathrm{Nd}$ & $\mathrm{Sm}$ & $\mathrm{Eu}$ & $\mathrm{Gd}$ & $\mathrm{Tb}$ & Dy & $\mathrm{Ho}$ \\
\hline 55 & 28 & 55.8 & 6.94 & 30.7 & 6.5 & 0.59 & 6.23 & 0.97 & 5.45 & 1 \\
\hline 53 & 4.6 & 10.1 & 1.29 & 6.5 & 1.9 & 0.56 & 2.36 & 0.42 & 2.75 & 0.56 \\
\hline 49 & 12.3 & 23.9 & 2.7 & 11.7 & 2.4 & 0.56 & 2.57 & 0.45 & 2.83 & 0.58 \\
\hline 50 & 14.5 & 27.4 & 3.04 & 13.5 & 2.7 & 0.62 & 2.83 & 0.45 & 2.8 & 0.56 \\
\hline 51 & 9.8 & 19.8 & 2.25 & 9.3 & 2.1 & 0.49 & 2.09 & 0.36 & 2.21 & 0.45 \\
\hline Sample & $\mathrm{Er}$ & Tr:? & $Y b$ & $\mathrm{Lu}$ & $\mathrm{Eu} / \mathrm{Eu}^{\star}$ & & & & & \\
\hline 55 & 2.81 & 0.4 & 2.61 & 0.36 & 0.28 & & & & & \\
\hline 53 & 1.69 & 0.26 & 1.72 & 0.25 & 0.81 & & & & & \\
\hline 49 & 1.70 & 0.25 & 1.85 & 0.26 & 0.69 & & & & & \\
\hline 50 & 1.70 & 0.25 & 1.72 & 0.26 & 0.69 & & & & & \\
\hline 51 & 1.37 & 0.21 & 1.35 & 0.21 & 0.72 & & & & & \\
\hline
\end{tabular}




\subsection{Metamigmatites}

\subsubsection{Major and Trace elements}

The major element compositions of the leucosomes are close to the cotectic line of $2 \mathrm{kbar}$ in the normative Qtz-Ab-Or die gram (Fig. 8). Melanosomes are characterized by low $\mathrm{SiO}_{2}$ and high $\mathrm{Al}_{2} \mathrm{O}_{3}$, $\mathrm{Fe}_{2} \mathrm{O}_{3}, \mathrm{TiO}_{2}, \mathrm{~K}_{2} \mathrm{O}$ and $\mathrm{Rb}$ contents. The $\mathrm{K}_{2} \mathrm{O}$ and $\mathrm{Rb}$ contents are in accordance with the biotite enrichment in melanosomes in comparison to the neighbouring leucosomes.

The trace element contents of the leucosomes (compared to those of mesosomes) are enriched in $\mathrm{Sr}, \mathrm{Ba}, \mathrm{U}$, Th and depleted in $\mathrm{Nb}, \mathrm{Y}, \mathrm{Ti}, \mathrm{Zr}$, (Fig.9) signifying partial melting and melt extraction from the residual material enhancing the migmatitic nature of the metamigmatite.

\subsection{Leucocratic phengite-orthogneisses}

\subsubsection{Major and Trace elements}

The leucocratic pheirgite-orthogneisses have a granitic composition with $\mathrm{SiO}_{2}$ content ranging between $68-73 \%$. The major element compositions show that they are ultrapotassic, peraluminous with S-type character (Tab. 2). All samples are of subalkaline affinity and belong to the calc-alkaline series. The $\mathrm{K}_{2} \mathrm{O}$ vs $\mathrm{SiO}_{2}$ relations show high-K affiliation. The normative corundum and the high ASI(>1.3-2.2) (Tab.2) further argue for the S-type character with a high degree of peraluminosity. Major and trace element variations demonstrated in Harker diagrams (not shown in this paper) indicate decrease of $\mathrm{TiO}_{2}, \mathrm{Al}_{2} \mathrm{O}_{3}, \mathrm{Fe}_{2} \mathrm{O}_{3}, \mathrm{MgO}$ and $\mathrm{P}_{2} \mathrm{O}_{5}$ abundances and increase of $\mathrm{K}_{2} \mathrm{O}$ with increasing $\mathrm{SiO}_{2} \cdot \mathrm{Na}_{2} \mathrm{O}+\mathrm{K}_{2} \mathrm{O}$ remains nearly constant. The samples with exceptionally high $\mathrm{K}_{2} \mathrm{O}$ contents show always very low contents in $\mathrm{Na}_{2} \mathrm{O}$. This is attributed to potassic metasomatism occurred during ultramylonitizatioli of the orthogneisses during the exhumation.

The phengite-orthogneisses are characterized by high values of $\mathrm{Rb} / \mathrm{Sr}, \mathrm{K} / \mathrm{Rb}$ and low values of $\mathrm{Rb} / \mathrm{Zr}(<1.7)$. The enrichment in incompatible elements such as $\mathrm{K}, \mathrm{Rb}$, Th and $\mathrm{U}$ with respect to $\mathrm{Nb}$ and $\mathrm{Ti}$ (HFSEs) strongly supports the involvement of crustal component. Trace element variation displayed on primitive-mantle normalized spidergrams (Fig. 10a) show a relative depletion in $\mathrm{Ba}$, $\mathrm{Sr}, \mathrm{P}$ and $\mathrm{Ti}$. Trace element variation normalized to the hypothetical Ocean Ridge Granite (ORG) of Pearce et al. (1984), (Fig. 11) indicate an enrichment in the LILE (K, Rb, Ba).

Using the $\mathrm{Rb}$ vs $\mathrm{Y}+\mathrm{Nb}$ discrimination diagram (Fig. 12) for granitic rocks (Pearce et al 1984), the phengite-orthogneisses from Pentelikon Mountain plot in the field of volcanic arc setting. Three samples which are cha acterized by high potassium contents $(7.4-9.5 \%)$ and low sodium (0.42$0.98 \%$ ) (due to potassium metasomatism), plot outside this field.

\subsubsection{REE patterns}

The Chondrite-normalized REE pattern of one sample is shown in figure 13. The mean $\mathrm{REEE}$ content is $132,74 \mathrm{ppm}$. The chondrite-normalized REE patterns are strongly fractionated ( $\left.[\mathrm{La} / \mathrm{Yb}]_{\mathrm{N}}=7.7\right)$ and enriched in the LREE compared to the HREE. It also shows a pronounced negative Eu anomaly $\left(\mathrm{Eu} / \mathrm{Eu}^{*}=0.28\right)$ indicative of plagioclase fractionation.

\subsection{Amphibole-epidote-albite-orthogneisses}

\subsubsection{Major and Trase elements}

The amphibole-epidote-albite-orthogneisses have dioritic to granodioritic composition, with $\mathrm{SiO}_{2}$ ranging from $49-66 \%$ (Tab. 2). They have a transitional character between S- and I-type and calcalkaline affinities.

Major and trace element variations demonstrated in Harker diagrams (not given in this paper) show $\mathrm{TiO}_{2}, \mathrm{Al}_{2} \mathrm{O}_{3}, \mathrm{Fe}_{2} \mathrm{O}_{3}, \mathrm{MnO}$ and $\mathrm{MgO}$ decrease and $\mathrm{P}_{2} \mathrm{O}_{5}$ increase with increasing $\mathrm{SiO}_{2}$. $\mathrm{Rb}$ and $\mathrm{Ba}$ are enriched relative to $\mathrm{Sr}$, indicating high $\mathrm{Rb} / \mathrm{Ba}$ and $\mathrm{Rb} / \mathrm{Sr}$ ratios and low $\mathrm{Sr} / \mathrm{Ba}$ ratios. Primitive-mantle normalized spidergrams (Fig. 10b) show enrichment in elements (e.g. Rb, Th, K and $\mathrm{U}$ ) and negative anomalies in HFSE elements, $\mathrm{Nb}$ and $\mathrm{Ti}$, which are indicative for volcanic arc setting. The volcanic arc character is also strengthened by the low $\mathrm{Rb} / \mathrm{Zr}(<0.9)$ and $\mathrm{Rb} / \mathrm{Cs}(<36)$ ratios, which are similar to arc magmas reported by Harris et al., (1986) and Hart \& Reid (1991) respectively. The $T a / Y b$ vs $T h / Y b$ plots (Fig. 14) tend to have high $T h / Y b$ and intermediate $T a / Y b$ ratios. The high $T h / Y b$ ratios indicate involvement of crustal material. 


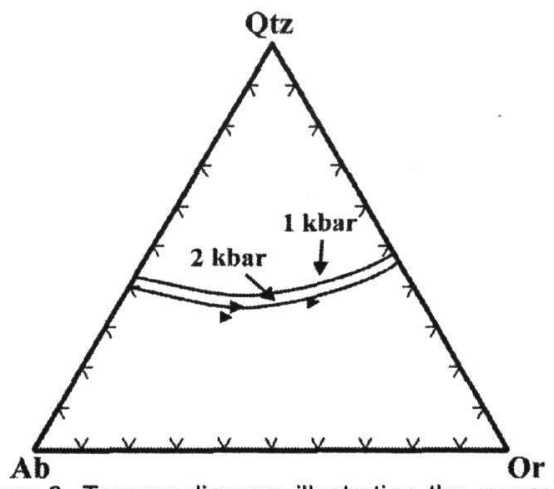

Figure 8. Ternary diagram, illustrating the normative Qtz-Ab-Or compositions of leucosomes. They plot close to the cotectic line of $2 \mathrm{kbar}$. Ebadi \& Johannes (1991).

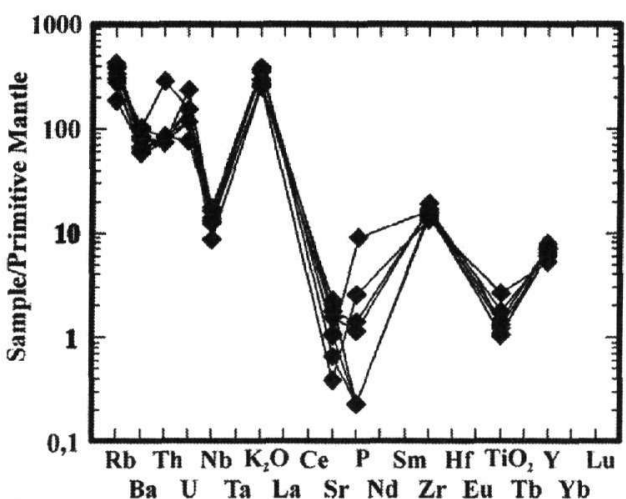

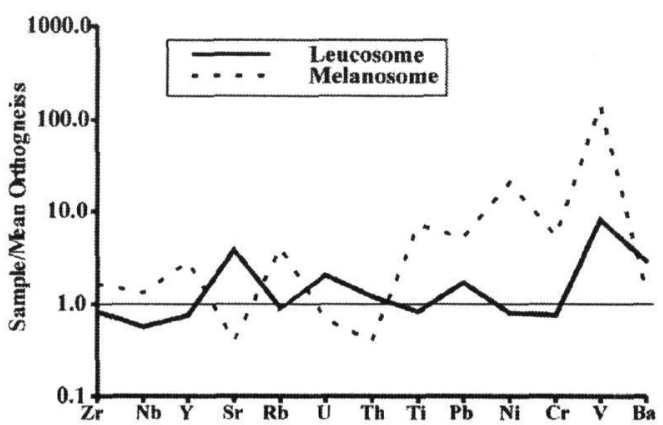

Figure 9. Trace element variations of leucosome and melanosome normalized to a mean orthogneiss sample.

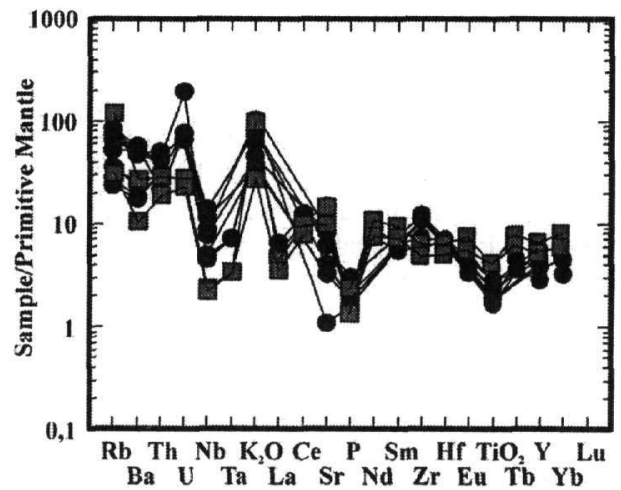

Figure 10. Trace element ć bundance normalised to primitive mantle. (a) Phengite-orthogneisses are characterized by strong negative $\mathrm{Nb}, \mathrm{TiO}_{2}$ and $\mathrm{P}$ anomalies. (b)Amphibole-epidote-albite-orthogneisses are characterized by moderate negative $\mathrm{Nb}, \mathrm{TiO}_{2}$ and $\mathrm{P}$ anomalies. Diamonds: phengite orthogneisses; filled boxes: dioritic orthogneisses; filled circles: granodioritic orthogneisses. The normalizing values are from Sun \& McDonough (1989)

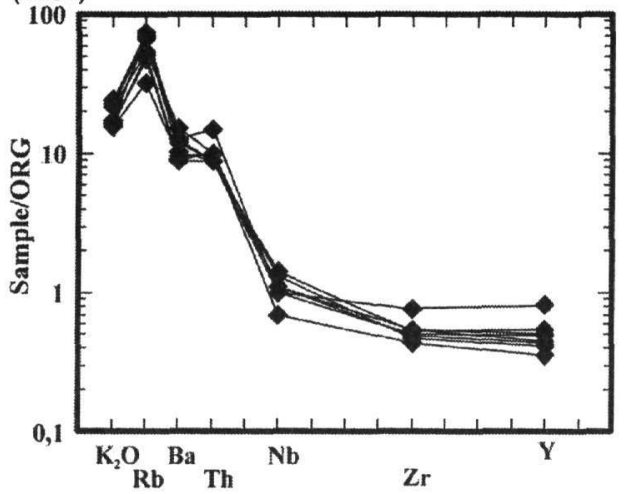

Figure 11. Ocean-ridge gr anites normalized spidergram for phengite orthogneisses showing enrichment of LILE relative to HFSE. Pattern normalizing values are from Pearce et al. (1984).

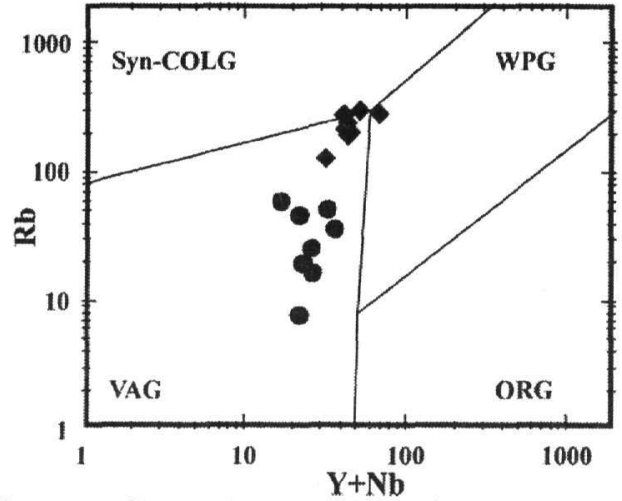

Figure 12. Chemical compositions of the granodioritic to granitic orthogneisses in the Rb vs. $\mathrm{Y}+\mathrm{Nb}$ discrimination diagram of Pearce et al. (1984). They plot in the volcanic arc field (VAG). 


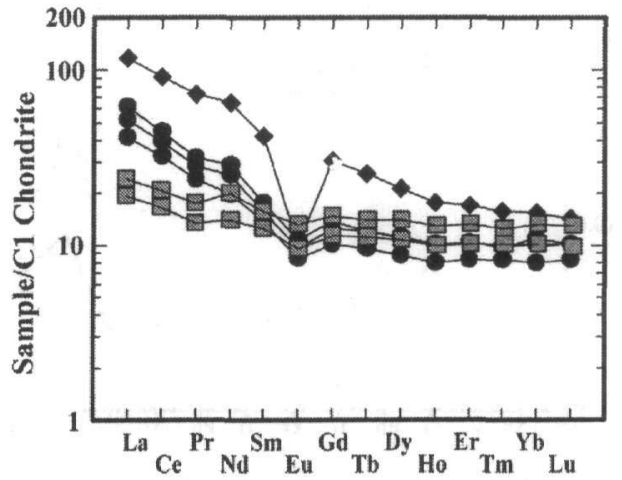

Figure 13. Chondrite-normalized REE abundances for the orthogneisses. The symbols as in figure 10. The normalizing values are from Sun \& McDonough (1989)

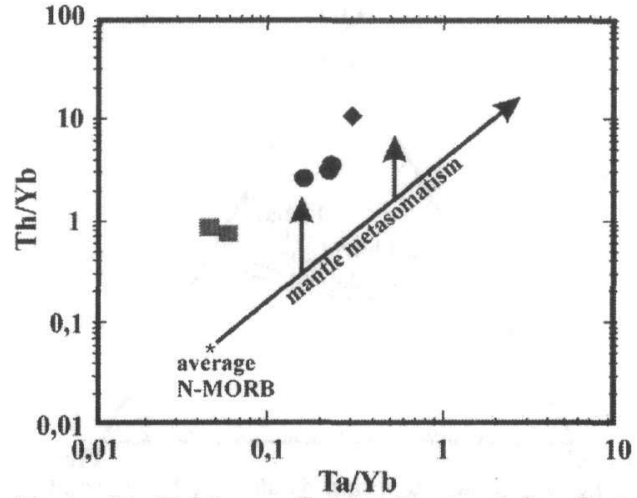

Figure 14. Th/Yb vs. Ta/Yb diagram (after Pearce 1983) for the orthogneisses showing the influence of crustal component.

\subsubsection{REE patterns}

In amphibole-epidote-albite-orthogneisses the $\Sigma R E E$ content ranges from 52 to $72.33 \mathrm{ppm}$ in the granodioritic and from 34.98 to $45.67 \mathrm{ppm}$ in the dioritic ones. Chondrite-normalized REE patterns (Fig. 13) indicate fractionation between the light and heavy REEs. They exhibit moderately fractionated LREEs $\left([\mathrm{La} / \mathrm{Sm}]_{N}=3.26\right)$ and flat HREEs $\left([\mathrm{Gd} / \mathrm{Yb}]_{N}=1.25\right)$ patterns in the granodioritic, and slight to non-fractionated REE patterns in the dioritic $\left([\mathrm{La} / \mathrm{Sm}]_{N}=1.56\right.$ and $\left.[\mathrm{Gd} / \mathrm{Yb}]_{N}=1.13\right)$. They show a slight negative $\mathrm{Eu}$ anomalies $\left(\mathrm{Eu}^{\mathrm{E}} \mathrm{Eu}^{*}=0.69-0.81\right)$, which indicates fractionation of small amounts of plagioclase.

\section{DISCUSSION AND CONCLUSIONS}

In Pentelikon Mountain metamigmatites and orthogneisses occur as tectonic slices in the calcschists or between calc-schists and marbles. Metamigmatites still preserve their migmatitic fabrics, indicated by alternating 'eucocratic and melanocratic layers, lenses of melanosomes in migmatites showing a higher degree of melting, and deformed aplitic and pegmatitic dykes. The major element composition of leucosomes has normative Qtz-Ab-Or compositions close to the cotectic line of 2 kbar. Melanosomes are indicated by low $\mathrm{SiO}_{2}$ and high $\mathrm{Al}_{2} \mathrm{O}_{3}, \mathrm{Fe}_{2} \mathrm{O}_{3}, \mathrm{TiO}_{2}$ and $\mathrm{K}_{2} \mathrm{O}$ contents, which are in accordance with the predominance of biotite.

Major, trace and REE element concentrations indicate that the protoliths of the orthogneisses have calc-alkaline affinity in a magmatic arc setting. The trace element patterns show enrichment in LIL relative to HFS elements, supporting the involvement of crustal component in magma generation, also enhanced by the negative anomalies in $\mathrm{Nb}, \mathrm{P}$ and $\mathrm{Ti}$ and the $\mathrm{Th} / \mathrm{Yb}$ vs $\mathrm{Ta} / \mathrm{Yb}$ relations.

Dioritic orthogneisse; show a relatively high values of $\mathrm{Mg \#}(>44)$, low contents of $\mathrm{Na}_{2} \mathrm{O}(<3 \%)$, nearly unfractionated HREE abundances (Fig. 13) with low [La/Yb] values and relatively high abundances of $\mathrm{Y}$. All these preclude the origin of the dioritic magma by dehydration melting of mafic protoliths as well as the involvement of garnet as residual phase in the magma source or as part in a fractionating assemblage. The lithospheric mantle seems to be one of the probably sources of the parental magma (Altherr et al. 2000).

The protoliths of granitic and granodioritic orthogneisses are probably formed from crust-derived felsic magmas. The high molar $\mathrm{Al}_{2} \mathrm{O}_{3} / \mathrm{MgO}+\mathrm{FeOt}$ (molar $\mathrm{A} / \mathrm{FM}$ ) (1.26-3.85) and low molar $\mathrm{CaO} / \mathrm{MgO}+\mathrm{FeOt}$ (molar $\mathrm{C} / \mathrm{FM})(0.02-0.20)$ values, and the strongly fractionated REE patterns suggest a possibly derivatic $n$ of the granitic magma from a metapelitic source enriched in LREE contents with plagioclase as major fractionating phase. For granodioritic orthogneisses the low A/FM (0.43-0.96) and high C/FM (0.52-0.93) molar values, the fractionation of LREE and the enrichment of LILEs support magma derivation by dehydration melting of metaigneous protoliths and plagioclase as major fractionating phase (Patino Douce \& Beard 1995, Singh \& Johannes 1996). 
To conclude the metamigmatites, that represent Pre-Alpine rocks and the orthogneisses are tectonically intercalated in the metasedimentary rocks that have Alpine protolith ages. All rock types underwent a common HP/LT Alpine metamorphism. The formation of the protoliths of the orthogneisses may be related to magmatic event(s) in an arc setting. Since absolute ages for the magmatic protoliths of the orthogneisses are not available two alternative scenarios are possible for the magmatic event(s). (a) The orthogneisses represent magmatic rocks of the Pre-Alpine basement. (b) They have an Early Alpine age (i.e. Triassic) and intruded/extruded in the associated sediments. In the second scenario, during Triassic time subduction of an inferred ocean separating the Apulian microplate from Gondwana like that proposed by Pe-Piper (1982) must be invoked. If the first scenario is valid, the orthogneisses and the metamigmatites may represent either basement rocks of the Cycladic complex or slices from an overlying continental block (i.e. Pelagonian zone) tectonically intercalated into the metasediments of the subducted slab (Apulian plate).

\section{ACKNOWLEDGEMEIITS}

We are very grateful to $\mathrm{A}$. Liati. and an anonymous reviewer for their critical reading and constructive comments contributing to improvement of this paper. Sincere thanks are also due to the Greek Science Foundation (IKY) scholarship for the financial support to Baziotis I.

\section{REFERENCES}

Altherr R., Holl A., Hegner E., Langer C. \& Kreuzer H. 2000 High-potassium, calc-alkaline I-type plutonism in the European Variscides: rnrthern Vosges (France) and northern Schwarzwald (Germany). Lithos. 50, 51-73

Andriessen P.A.M., Banga G. \& Hebeda E.H. 1987 Isotopic ages study of pre-alpine rocks in the basal units of Naxos, Sikinos, los, Greek Cyclades. Geologie Mijnb., 66, 3-14

Baziotis I., Mposkos E. \& Perdikatsis V. 2004 Alpine high-pressure/low-temperature metamorphism in Penteli area (NE Attica, Greece). 32th Int.Geol.Con.,Florence.

Ebadi A. \& Johannes W. 1991 Beginning of melting and comparison of first melts in the system Qz-Ab-Or- $\mathrm{H}_{2} \mathrm{O}-$ $\mathrm{CO}_{2}$. Con.Min.Pet., 106,286-295

Engel, M. \& Reischmann, T. 2001 Upper Carboniferous magmatism in the central Aegean region: evidence from basement gneisses of the Cyclades. J. Conf. Abs. 6, 318.

Harris N.B.W., Pearce J.A. \& Tindle A.G. 1986 Geochemical characteristics of collision-zone magmatism. In: Coward M.P. \& Ries A. . . (eds.) Collision Tectonics.Geol.Soc.Spec.Publ.19,67-81

Hart S.D. \& Reid M.R. 1991 Rb/Cs fractionation: A link between granulite metamorphism and the S-process. Geochimica et Cosmochimica Acta, 55, 2379-2383

Katsikatsos G. 1977 La structure tectonique d'Attique et de l'ile d'Eubee. Reun.extr.des.Soc.Geol de France et de Grece, 1976, Bull.Soc. Geol.France, 19, 75-80

Kessel, G. 1990 Untersuchungen zu Deformation und metamorphose im Attischen Kristallin, Griechenland. Berliner Geowissenschaft. Abhandlungen, Reihe A, Band 126, Berlin, $150 \mathrm{~S}$

Lozios S. 1993 Tectonic analysis of the metamorphics of NE Attica (Greece). Ph.D. thesis, University of Athens, 299pp (in Greek with English abstract)

Patino Douce A.E. \& Beard J.S. 1995 Dehydration-melting of biotite gneiss and quartz amphibolite from 3 to 15 kbar. J.Petrol., 36, 707-738

Pearce J.A. 1983 Role of the sub-continental lithosphere in magma genesis at active continental margins. In: Hawkesworth C.J. \& Norry M.J. (eds.), Continental Basalts and Mantle Xenoliths. Shiva, UK, 230-249

Pearce J.A., Harris N.B.W. \& Tindle A.G. 1984 Trace element discrimination diagrams for the tectonic interpretation of granitic rocks. J. Petrol., 25,4, 956-983

Pe-Piper G. 1982 Geochemistry, tectonic setting and metamorphism of mid-Triassic volcanic rocks of Greece. Tectonophysics, $85,253-272$

Singh J. \& Johannes W. 1996 Dehydration melting of tonalities: Part II. Compositions of melts and solids. Con.Min.Pet., 125, 26-44

Sun, S.S. \& McDonough, W.F. 1989 Chemical and isotopic systematics of oceanic basalts: implications for mantle composition an.1 processes. In: Saunders A.D. and Norry M.J. (eds.), Magmatism in ocean basins. Geol.Soc.London.Spec.Pub., 42, 313-345

Wijbrans J. R., Schliestedt M. \& York D. 1990 Single grain argon laser probe dating of phengites from the blueschist to greenschist transition on Sifnos (Cyclades, Greece). Con.Min.Pet., 104, 104, 582-593 